\title{
KELL-E ÉS LEHET-E A NÉPHAGYOMÁNYT TANÍTANI/TANULNI?
}

\section{Géczi-Laskai Judit}

Eötvös Loránd Tudományegyetem, Tantó- és Óvóképző Kar

\section{A posztmodern kor kihívásai és a honismeret - néphagyományőrzés}

„Nagy a ma élő és alkotó értelmiség felelőssége, mert korszak- és kultúraváltás idején élünk. Olyan korban, amikor veszélyeztetett az emberiség jövője és kultúrája, amikor a hagyományok örzése és átemelése az új évezred kultúrájába a Föld és Európa nemzeteinek létezése, identitása szempontjából meghatározó jelentőségü." (Kraiciné 1998. 15. o.) - fogalmazódott meg lassan tizenöt éve, a hon- és népismeret, és a néphagyomány oktató-, nevelőmunkájának kapcsolatáról.

Andrásfalvy Bertalant, a néphagyomány mai funkcióinak kutatójaként is elismert szakember karakteres álláspontját idézve az 1970-es évektől kialakult ezredvégi „zavarnak”, a technikai, népességbeli, információ-robbanás okozta széteső modern kultúra hátrányának és a hatására kialakult keserü szájízü jelenség az úgynevezett posztmodern, ${ }^{1}$ amelyben meginogni látszanak a korábbi egységes, abszolút érvényü, a világot megmagyarázó elvek (Andrásfalvy, 1998). Helyükbe a világot többértelmünek, heterogénnek láttató, ellentmondásokkal teli vélemény került, amelyben a korszellemet, kultúrát, látásmódot, önmaga útját kereső ember továbbra is dilemmákkal küzd.

Ezek a jellemzők ma is helytállóak. A posztmodern kultúrában a modernizmus általános kritikája és újraértelmezése, a modernség és a tradíció szövetségének megtalálása, a szubjektivitás és a személyi autonómia hangsúlyozása, az egyidejü folytonos változatosság és a történetiség szempontjainak érvényesítése egyaránt megtörténik. Az új évezred elején igazolódni látszik az az ezredvégi előrevetítés, amelyben növekvő szerepet kapnak a nemzeti identitás alapját képező hagyományok, amelyek pusztulása, leépülése feledésbe merülése világjelenséggé növekedett. Nemcsak Európa, hanem Magyarország fennmaradásának is egyik kulcskérdésévé vált a néphagyományok megörzése, megismerése, a már elkezdődött évezred kultúrájába történő átmentése.

Ezt igazolja Hermann Bausinger megközelítése, akinek gondolatai arról győzhetnek meg, hogy a jelenséget nem lehet magyar sajátosságnak minősítenünk. A „térbeli expanzió”-nak nevezett szemlélete, más népek, területek hagyományait nem ismerve hajlamos a népi kultúra minden megnyilvánulását az adott helyi tradíció alkotórészének tekinteni (Bausinger, 1995).

Heller Ágnes szerint; ,[...] a posztmodern látásmód viszont nem áll kívül a modernitáson [...] buzgó erőfeszítéseink szétrombolhatják, de nem hagyhatják maguk mögött a modernitást.” (Heller, 1992. 564. o. idézi Fehér, 2010).

\footnotetext{
${ }^{1}$ Ide kívánkozik „fékként és ellensúlyként,” hogy szakmánkban például a Mihály Ottó által a neveléstudomány számára értelmezett posztmodern filozófia - a pedagógia tudomány voltának, tudományosságának akár megkérdőjelezésével is, a nyelv, az ember, a személyiség megközelítésével is szkepticizmusra int a nevelés univerzális legitimálhatóságát illetően. [...] A premodern és a modern (minden eddigi) pedagógia filozófiai bázisa az, hogy van valamilyen ,igaz” emberi természet, lényeg. A nevelésnek a posztmodern gondolkodásban nincs „eszménye” az emberről, sokrétű, a „milyennek kellene lenni”, a „milyennek érdemes lenni” látásmódja, de nincs egy olyan determináns kritériuma, hogy melyik az „igazi”. „A posztmodern filozófia többé nem úgy látja az emberiséget, mint valamilyen fejlesztendő vagy leküzdendő, értékes vagy értéktelen adottságokkal rendelkező fajt. Az emberről alkotott különböző eszmények, ideák csak adaptációs stratégiákat jelentenek. Egyik stratégia sem »emberibb«, mint a másik.” (Mihály, 2001. 4-16. o.)
} 
„A modem kor olyan volt, mint az akadályfutó, aki a szemét a célra szögezve csak futott, ledöntve a korlátokat. Minden cél egy-egy újabb akadálynak bizonyult, s a versenyző csak futott, futott. A posztmodern úgy látja, meg kell állnunk. Nem mintha elértük volna a célt, s nem is úgy, mintha nem is lennének céljaink. De a ledönthető korlátok már »ledöntettek«. Nézzünk most körül, s tanuljunk meg élni abban a világban, amelybe szerencsénkre, vagy szerencsétlenségünkre beleszülettünk!" (Baloghné, 2002. 22. o.).

Napjainkban az emberek néphagyományhoz való viszonya ellentmondásos: a hagyományőrzés és a hagyományoktól való elszakadás egyaránt jellemző, amely okát a releváns szakirodalmi utalások is keresik. A „hagyomány, hagyaték, örökség" mind olyan szellemi és tárgyi értékek, amelyek átörökítése, életben tartása, felidézése számos lehetőséget rejt magában; „[...] fejlődéslélektani és társaslélektani érvek csoportosíthatók arra vonatkozóan, hogy a »kulturális szocializációban« mennyire nélkülözhetetlen mindaz, amit »anyanyelvi nevelésnek « nevezünk, értve ezen zenei, vizuális, a mozgáskultúra anyanyelvét. A modern világ identitásproblémájának kezelésében is kimutatható a néphagyomány ébrentartásának-rekonstrukciójának a lehetősége." (Trencsényi, 1993. 98. o.).

E megközelítés, az „együttélés megtanulása” pozitív vonása az, hogy a korszerű elfogadásával, új értékekkel való felruházásával, a modernhez való hozzáidomítással hirdeti a hagyományok felhasználhatóságát.

Gráfik Imre értelmezése szerint ez a folyamat, az úgynevezett kulturális tradíció: „A hagyomány és vele együtt a kultúra sokáig úgy szerepelt a néprajztudományon és a kulturális antropológián belül, mint a múlthoz sok szállal kötődő, a modernizáció hatásainak kiszolgáltatott életmód. Ez a fajta esszencialista felfogás az utóbbi húsz évben azonban egyre inkább a jelenség kritikusabb értelmezésének engedett teret. A hagyományt tehát ma sokan nem valami adott, változatlan vagy lassan módosuló, zárt dologként kezelik, hanem a kulturális érintkezések révén müködő, folyamatos változásban levő források sokféleségét. A radikálisabb irányzatok szerint a hagyomány, a kultúra maga az értelmezés folyamata, amely a jelen dolgainak úgy tulajdonít jelentést, hogy a múltra hivatkozik közben. Éppen ezért a hagyomány mindig csak a jelenben nyer jelentést, és sosem választható el az általuk adott interpretációktól." (Gráfik, 2007. 240. o.).

Kétségtelen, hogy napjainkban a néphagyományokat fel- és megidéző programok, a kézmüves technikával létrehozott termékek iránti érdeklődés és azok vonatkozásai (történeti, népmüvészeti, egyedi, autonóm, szimbolikus, identitást kifejező, esztétikai, természetes anyagfelhasználás stb. okokra visszavezethetően) hol erősebb, hol gyengébb, de folyamatos. Annak a sajátos metamorfózisnak vagyunk tehát tanúi, hogy a jelenkor - mégoly korlátozott érvényü - kereslete és kínálata, a múlt századok tradicionális müveltségének, a népi kultúrának tárgyait és jelenségeit sajátos módon kiemeli a tömegkultúra státuszából.

Józsa Péter szerint mindez csak az úgynevezett „,kulturális blokkba” tartozó személyekre vonatkozik, akik a történeti múlthoz, a hagyományos népi kultúrához, s annak tárgyi világához való viszonyában, s ennek következményeként szokásaiban és gondolkodásában hasonlatosak (Józsa, 1986). A jelenség jól érzékelhető, bár pontos felmérések tudomásom szerint nincsenek arról, hogy a lakosság egészére vetítve milyen arányt képviselnek. Voigt Vilmos szerint ez a népmüvészeti tradíciókra (tudatosan) alapozó/építő szemlélet és gyakorlat lényegében a folklorizmus folyamatába illeszkedik (Voigt, 1990). 
A felvázoltak lényegileg a néprajztudomány által kutatott és leírt jelenségét, a folklorizálódás folyamatát érzékeltetik. S noha e fogalom eredetileg olyan néprajzi kategóriaként jött létre, amely a historizmus hétköznapi kultúrához való viszonyát és a populáris kultúra újjáélesztésének folyamatát volt hivatott jelölni, az utóbbi években a népi kultúra központi kategóriájává vált. A leírt folyamat azonban müködik, sőt már neofolklorizmusról is beszélünk, s nem lehetetlen, hogy a posztfolklorizmus gondolata, illetve fogalma is elökerül majd. A fiatalabb generációk körében a folklorizmusnak van egy más motivációja is; „Az emberekben, különösen a kereső fiatalokban valami vágy, valami kielégítetlenségi érzés támadt föl, amelyre választ, megoldást bizonyos egyszerü, a néphagyományban megtalálható módszerek, formák, cselekedetek kínálnak. [...] Ezt bizonyítja, hogy a néphagyományt kialakító igények, szükségletek tovább élnek az attól már eltávolodott nemzedékekben is, és ugyanezek teremtik meg a néphagyomány utóéletét, az ún. folklorizmust is" (Andrásfalvy, 2004. 225. o.).

Egykor a népi társadalom önfenntartása alapján gondoskodott az élethez szükséges gyakorlati tudás átörökítéséről, a munkára nevelésről, és az élet szerves részeként a szórakozást nyújtó alkalmakról is. A falusi népiskolákban nem kellett a paraszti létről tanulniuk, hiszen a napi életük része volt, illetve szokás szerint a család tapasztaltabb tagjai tanították a fiatalabbakat. A 19. századi polgárosodás, a munkamegosztás, a müszaki fejlödés néhány olyan újítással járt, - amely gyakran szembekerült a néphagyománnyal, mint müveltséggel, egyben a paraszti kultúra gyökeres változását indította el. Az urbanizáció eredménye lett a természet-közeli közösségektől eltávolodó, modernebb életformák, új típusú közösségek, vagy éppen közösségpótló, új művelődéskonstrukciók létrejötte. A jelenség kritikai reflexiójaként alakultak ki hazánkban is az olyan ún. életreform-mozgalmak, amelyek a változásokat romlásnak, ,az idill, az aranykor” társadalmi méretü végének tekintették, és mikroközösség-szigetek létrehozásának keretei közt (pl. a gödöllői művésztelep), az emberi világ meggyógyulásának lehetőségét keresték (Németh, 2005). Andrásfalvy Bertalan „felvilágosult gőgnek” minősítette a néphagyományt lenéző, abban csak a megrögzött, visszahúzó elavult tradíciót látó szemléletet, amely a városi kultúra, polgárság, jellemző mércéjévé vált (Andrásfalvy, 1988).

Sajnos abban az iskoláknak is szerepe volt, hogy intézményeivel, módszereivel, ismeretanyagával a hagyományos paraszti kultúrát szétzúzta. A társadalmi, rokoni, korosztályi, baráti közösségek szétesésével egyre több feladat hárult rá, de nem tudta pótolni az egykori közösségek tanító-nevelő szerepét. A tanítás tartalma egyre inkább a rációt, a természettudományos ismereteket részesítette előnyben, így nem vállalhatta a néphagyomány rendszerezetlen gyakorlati ismereteit.

„Ami dacolt az idővel, annak egyszerüen jónak kell lennie” - Bausinger olyan német ifjúsági mozgalomról ír, amelynek tagjai a régi hagyományok, az ősi múlt felé fordulást választották. A 19. század folyamán populárissá vált „magatartást, a népi kultúra markáns meghatározójának értékeli, ugyanakkor a kultúra- és a társadalomtörténet folyamán a néphagyományhoz való viszonyulást, egy elmúlt, lezárult „müveltségi egészhez” mindenütt az adott pillanatban megtörténőnek tekinti. ,[...] értelmetlen dolog a népi kultúrát a paraszti életmód érintetlen-folyamatos formájaként elkülöníteni, inkább a mindenkori történetileg változó mivoltában kell leírni és megérteni” (Bausinger, 1995. 166. o.).

A tanulmány bevezetésében a néphagyomány felelevenítésében és ápolásában, a hangsúlyváltásokat eredményező, változó értékeit előtérbe helyező 
társadalomrajz érintőleges bemutatására vállalkoztam, mert az előzmények tömör felvázolása nélkülözhetetlen a néphagyományok jelenkori oktatásbeli szerepének megértéséhez.

A továbbiakban a néphagyomány jelenlétének „plurális” tüneteinek átgondolása is lényeges, az esetleges manipuláció vagy a populizmus jelenségektől a társadalomszervező, értékteremtő kérdéskörét belefoglalva, nemkülönben az „ellenkulturális értelmezések” akár a mindennapi élet szempontjából is. Ez utóbbit megfigyelve, mára az a tendencia kezd gyakorlattá válni, hogy egyre népszerübbek azok az újraéledő és szaporodó közösségi alkalmak, amelyek a néphagyományok felelevenítésére, az ünnepeket megújító szertartásokra vállalkoznak, melyeket az élhetőbb élet, a közösség iránti belső igény, az összetartozás élménye táplál.

„Az olyan ember lelke, aki nem tudja kezelni érzéseit, kiegyensúlyozatlan marad, türelmetlen, törékeny, magának való. Csak erős mérgekre érzékeny: üvöltő zenére, horrorra, szexre, erőszakra. Mert érzelemre mégis szüksége van, szomjas erre és keresi" (Andrásfalvy, 2010. 37. o.).

„Nem az a dolgunk, hogy nosztalgiát érezzünk mára eltünt szokások hiánya felett, hanem az, hogy észrevegyük mindazt, ami körülvesz minket. [...] A népi kultúrában élni elsősorban életet jelent..." (Kuncze 1993, 22. o.) A szabadelvüek ${ }^{2}$ a népi kultúráról az 1990-es évek elején Szatmárcsekén tanácskoztak. Kuncze Gábor markáns véleményében a nosztalgiázást kritizálja, amely úgy vélem, ténylegesen azoknak adatik meg, akik átélték az egykori hagyományőrző pillanatokat, s talán ők meg is tehetik ezt. Akik viszont nem, azok csak a hallottak alapján vágyakozhatnak az akkori szokásokra. Másik mondatában pedig a népi kultúrát azonosítja az élettel, amit azzal egészítenék ki, hogy a nélkül is van élet példa erre a korábban jellemzett mai világ -, de a néphagyományok vonzásában lehet szebb és jobb!

„[...] mindazok, akik a népi kultúrával foglalkoztak, olyan definíciót próbáltak adni a kultúráról, amely tágabban határozta meg azt, mint ahogy a "magas kultúra« müvész, filozófus, politikus civilizáció-fenntartó képviselői szokták. A magas kultúra produkcióin túl a kultúrába sorolták azokat az értékrendszereket, a nyelvi, díszítőmüvészeti, viselkedési formák, szimbólumok azon rendjeit, amelyekkel a mindennapi életben, a közösségi szertartásokon, a szóbeli kultúrákban lehet találkozni. Éppen ebből a tágabb kultúrameghatározásból született az az igény, hogy a kultúrának a különböző szintjeit, különböző típusait határozzák meg, majd ezeket különböző szociológiai, földrajzi, nemzeti alcsoportokra bontsák, tehát így különböztessenek meg a történelem folyamán egyházi, udvari, városi, paraszti kultúrát, olyan etnikus szubkultúrákat, amelyekben különböző - »elit, valamint népi« - alkotóelemei más és más kombinációban, eltérő rendszer szerint állnak össze" (Klaniczay, 1993. 113. o.).

Egyetértek Klaniczay Gábornak, a népi kultúráról megfogalmazott gondolataival, valamint Farkas Máriának, a néphagyomány tanításának összegzésével. „Előfordulhat, hogy az iskola által közvetített értékek és a mindennapok tapasztalatai konfrontálódnak, úgymint becsület, tisztesség, ügyesség, ügyeskedés. A múltismeret talán ahhoz nyújthat kapaszkodókat, hogy az iskolán kívüli tényezők hatása ne eméssze fel az iskolai szocializációt, segítse az értékpluralizmusok kezelését" (Farkas, 1997. 21. o.).

\footnotetext{
${ }^{2}$ Szabadelvűség: liberalizmus (a lain libertas/szabadság szóból), a tekintélyt tagadó és az egyéni szabadságot hangsúlyozó és érvényesítő szellemi áramlat. http://lexikon.katolikus.hu/S/szabadelvüség.html
} 
A néphagyományhoz való viszonyulás, tanulásának társadalmi és környezeti feltételei a körvonalazott évek során tehát gyökeresen megváltoztak és ez a változás, ahogy a jelenhez közeledünk, egyre gyorsabb.

Hermann Bausinger másokkal egyetemben a nép képzését nehéz, de döntő feladatnak látja, egyben a régi kötelékek felbomlását látva azt a dilemmát feszegeti, hogy elhalványul-e a régi népi kultúra javainak oktatásban betöltött értéke, vagy éppen most van a legnagyobb szükség a kötelékek tudatos beépítésre (Bausinger, 1995).

Világosan látszik, hogy egyre nagyobb feladat hárul az iskolára. Miért? Mert vállalnia kell azt a hiánypótlást, amely segít abban, hogy az emberek visszataláljanak a közösségi életnek lélektanilag mással nem pótolható megnyilvánulási formáihoz. Tanulmányomat részben azok a folyamatosan bővülő élmények inspirálják, amelyek hatására ezek a kérdések fogalmazódnak meg bennem: mit jelent személyemnek, szakmai irányultságomnak és szemléletmódomnak a néphagyományokkal való találkozás?

„A hagyományok ápolása olyan tevékenység, amely célja a múlt értékeinek átörökítése, feladata pedig a néphagyományőrzés lehetőségeinek megteremtése, amely már az óvodai nevelés folyamatában elkezdődik; ott a helye a gyermek játékában, versében, meséjében, zenéjében, alkotásában, mozgásában, táncában egyaránt. Eközben a kisgyermekkel megszeretteti a természetet, a környezetet, megismerteti a népi kultúra tárgyait, a népi müvészetet és a népszokásokat. Az eredmény az óvodáskor végére az, hogy a kisgyermek érdeklődve hallgat népzenét, népmesét, népi mondókát, szívesen játszik és alkot természetes anyagokkal, tárgyakkal, ízlésvilága befogadja a népi müvészet tárgyait, eszközeit, élvezi a közös ünnepeket, jeles napokat, hagyományőrző tevékenységeket.” Ezeket a gondolatokat nyolc éve hallottam Merényi Attilánétól, az óvodája innovációjáról szóló ismertetőjében. Akkor érzelmeimet és pedagógus énemet olyan mélyen és - immár büszkén vallom - örökre kitörölhetetlenül érintette ez a szemlélet (éppen középső gyermekemnek kerestünk óvodát), hogy azóta őszintén vallom, hogy az általam keresett utat találtam meg. Benedek Krisztina és Sándor Ildikó „Útravalói” (Benedek, 2006; 2010a) hatására teljes mértékben azonosulok gondolataikkal; „Hagyományaink egykor apáról-fiúra szájhagyomány útján szálltak, tölük kaptunk örökségbe, de mintha gyakran tétlenül néznénk háttérbe szorulását, elfelejtését. Ma a pedagógusok kezében van, hogy birtokba vegyék, megismerjék, újra fényesítsék és tovább adják az eleinktől kapott, élethosszig megőrzendő mesebeli kincseket." (Gécziné, 2009).

A néphagyomány-ismeret közvetítés fó problematikája, hogyan lehet a témát a posztmodern korban aktualizálni, érveket felsorakoztatni amellett, hogy miért érdemes visszatekinteni és tanulságokat levonni elödeink hajdani szellemi és tárgyi világából, ahol a természettel való harmónia, a kétkezi munka és az ősöktől örökölt bölcsesség volt az egyedüli lehetőség. Baloghné (2002) irányítja figyelmünket arra az alapvető kérdésre, hogy a rohanó - sokak által csak az anyagi javakért hajtó - jelenből a lassú léptékủ múltba történő visszapillantás rejtegethet-e emberi tartalmakat számunkra, és azok milyen minőségüek. Erre a válasz filozofikus is lehetne, ám a szerző sokkal mérvadóbbnak tartja a pszichés reakciók magyarázatait, illetve a (talán nosztalgikusnak vélt) érvrendszert, amely a természettel harmóniában, ökologikus szervességben, egyensúlyban élés vágyát hangoztatja az emberi ellenőrzés alól már-már kicsúszó technikalizáltság ellenében (Baloghné, 2002. 21. o.). 
A néphagyományok megőrzésére és továbbéltetésére már korábban is többféle út rajzolódott ki;

a) népi kultúra továbbfejlesztése magas, azaz a polgári/urbánus tradíciót is magába foglaló nemzeti kultúrává,

b) eredeti formájában megőrizni a paraszt müvészetként értelmezett népi múvészetet,

c) megtalálni a paraszt müvészet kapcsolatát a mai néphez, a munkássághoz (Fuchs, 2007).

Egy másik megközelítés szerint ${ }^{3}$ a néphagyományok két egymásra épülő, de mégis eltérö reprezentációja él:

a) a „szent néphagyomány”, amely a hagyományokkal szentségként bánva, az ún. őseredeti müvészeti-kulturális megnyilvánulásokat a kortársak okulására őrzi,

b) a profán megközelítés szerint pedig mindennapi praxisjellegü (a hétköznapi élethez szükséges készségek, képességek), és sajátos esztétikai minőséget is képviselő tudatformaként azonosítható (díszek, ábrázolások, zene, tánc, játék, imák, áldások, stb. illetve használatuk).

A Lágler Péter féle két aspektus azért is figyelemre méltó, mert az első azt az identitásközpontú interpretációt jelzi, amely a néphagyományok oktatásbeli szükségességét veti fel, míg a második a pedagógiához jól igazítható gyakorlatra utal; ,[...] az első erős és jól formált identitást kölcsönöz kidolgozott rituális kóddal és egész intézmény-rendszerrel, [...] a másik tág teret kínál az egyéni értelmezéseknek" (Lágler, 1981. 143. o.).

Meglátásom szerint az egyik járható út, ha a már bevált hagyományokat frissítjük fel és újmódi életünkhöz igazítjuk. Ezt igazolják a szüreti bálok, népes lakodalmak, a népdalkörök, farsangi mulatságok, táncházak és játszóházak, országszerte tapasztalható népszerúsége, amelyek a több évtizednyi kihagyás és rejtőzködés után megmutatják a paraszti szellemi és tárgykultúra szépségét, azaz „ritmusa kezd lenni az évnek, méltósággal tudunk ismét ünnepelni” (Baloghné, 2002). Lelki szükségleteinknek véleményem szerint jobban megfelel a szertartások, rítusok, ismétlődő alkalmak szertartásos vagy profán, emelkedett vagy évődő misztériuma, mint az évtizedekkel ezelőtt hivatalosan favorizált racionális életvitel egyhangúsága.

Viszont kulcskérdés, hogy a régi, öröklődő hagyományokat újra kell tanulnia annak a generációnak - beleértve magamat is - akik éltéből az egykor „,belenevelő folyamat” kimaradt. Ebben az újratanításban pedig kétséget kizáróan a legalkalmasabb - bár nem egyedüli - szereplő ma az iskola. Ebből következik az, hogy a posztmodern szemlélet képes a néphagyomány rehabilitációjára.

Másfelöl a természet, a gazdálkodás, a társadalom és a szellemi kultúra kapcsolódási pontjait - és nem csupán a részleteit - is meg kell ismernünk; „A néprajz tárgy az egy hagyományrendszer, s ez által rend és értékrend, kultúra és kontinuitás is, a tanítás pedig a tudás átadásán túl értékrendnek és szemléletnek továbbörökítése is. A néprajztanítás nem engedhet ebböl, és nem degradálódhat lexikális anyaghalmaz leadásával!” (Ágh, 1998. 38. o.).

${ }^{3}$ A hivatkozás Lágler Péter tanulmánya, ami a Nemzeti Kulturális Alapprogram Népművészeti Szakmai Kollégiuma által kiírt „Népmüvészeti kommunikációs stratégia és cselekvési terv” címü pályázatra készült. 


\section{Interdiszciplináris kapcsolatrendszer - A néprajzi témakör specialitása}

A néphagyomány-ismeret körébe utalható fogalomrendszerek korábbi részletes feltárása során ${ }^{4}$ egyértelművé vált, hogy a néprajz a történettudománnyal, az esztétikával, az irodalomtudománnyal, a müvészettörténettel, a szociológiával és a különféle gazdaságtudományokkal egyaránt kapcsolatban álló diszciplína. De a több tudománnyal fennálló kohézió esetünkben sem jelentheti azt, hogy a tartalom egyben a tudományok leképeződése. A komplex tudományos nevelés lehetőségeinek e kérdéskörét elemzők rámutattak a komplex egészként való szemlélés jelentőségére is: „Napjaink oly fontos, nemegyszer globális problémái, természettudományos feladatai sohasem külön fizikai, biológiai vagy kémiai problémaként jelentkeznek [...], hanem az elöbbi folyamatok egymásra hatásaként jönnek létre." (Németh, 1973; Radnóti, 1995. 79. o.)

Az évszázadok során a különféle tudományszakok egymástól független, feltárt ismereteinek egymásba kapcsolódását példázza tehát a néphagyományismeret is. A továbbiakban azokat a tárgyi specifikumokat gyüjtöttem össze - a szakirodalmak segítségével, illetve személyes tapasztalataim alapján -, amelyek arra keresik a választ, hogy milyen célok valósulhatnak meg a néphagyomány tanítása során és melyek a tananyag meghatározásának problémái.

Maga a néphagyomány tanítása egyedi lehetőség, a történetiségét és a nevelési hatásait tekintve. A néphagyomány-ismeret körébe utalható tudásrendszerek és pedagógiai/iskolai alkalmazásuk fejlődésének tudománytörténetéböl, az ismeretek oktatásának a 17. századra visszanyúló kezdeményezéseiböl arra lehet következtetni, hogy már akkor felismerték a nevelés folyamatában betöltött fontos szerepét. Megállapítást nyert, hogy a néphagyomány köznevelésbeli szerepvállalása kezdetben nem tudományos indíttatású volt, de a másfél évszázados folyamat egy új, a neveléssel szoros kapcsolatban álló tudomány megszületését tette lehetővé. A néphagyománytartalmú tankönyvi előzmények példái pedig azt mutatják be, hogy a néprajzi tartalmak évszázadok óta tetten érhetők, bizonyítva annak fontosságát és létjogosultságát. Korábban már kirajzolódott az is, hogy a néphagyomány különleges univerzális tudásanyaggal rendelkezik, legföbb tulajdonsága, hogy a különböző területei, müfajai és egyes elemei között úgynevezett szinkretikus összefüggés van ${ }^{5}$. Produktumainak elsajátítása és művelése nem egyenlő csupán a népi kultúra megismerésével, de termékeny táptalaja a kultúra egészére vonatkozó komplex ismeretekben való jártasságnak.

„A népi kultúra elkerülhetetlen felszámolódása, felbomlása után a hagyomány értékeinek a korszerü müveltségbe kell beépülniük" (Tarján, 1995. 10. o.). A néphagyomány-ismeretet a szokásos elméleti vagy gyakorlati jellegü besorolásban sajátos hely illeti meg. Nem köteleződik el egyik irányba sem, mert egyértelmüen kapcsolódik a közismereti (humán- és természettudományos) területekhez.

A néphagyomány taníthatóságának elméleti és gyakorlati alapja, a korszerü müveltség követelményeinek sorában szereplő hon- és népismeret, amely a különböző műveltségi területek (Anyanyelv és irodalom, Ember és társadalom, Társadalmi, állampolgári és gazdasági ismeretek, Emberismeret, Földünk és

\footnotetext{
${ }^{4}$ Kiterjedt feltárásban dolgoztam fel a témában releváns, sokszor vitatott, különböző tudományos paradigmák, olykor ideológiailag is meglehetösen telítetten fogalmazott definícióit. (Gécziné, 2011)

${ }^{5}$ Részletesebben lásd a szerző doktori értekezésében (Gécziné, 2013).
} 
környezetünk, Művészetek, Tánc és dráma) fejlesztési követelményei között jelentős mértékben helyet kap ${ }^{6}$.

Baloghné Zsoldos Julianna (2002) szerint a néphagyomány közvetítése, a leíró humán tudomány leképezése, amely a társadalom- és a természettudományok (azaz a reál- és a humántárgyak) közötti korábbi éles, de már elmosódni látszó határok példája. Ezért egyre inkább szükséges a folyamatok több oldalról történő vizsgálata és erre nagyon jó lehetőséget kínál a néphagyomány-ismeret. A néprajzi ismeretek megértéséhez a természettudományos alapok nélkülözhetetlenek (például biológia, meteorológia, földrajz, csillagászat szemszögéből taglalt népi gazdálkodás), de egyben humán tudomány is, amely magát az emberi kultúrát (történelem, irodalom, nyelvészet) is vizsgálva, mégsem azonosul az irodalom vagy történelem tantárgyi jellegével.

Kettős szemszögből vizsgálhatók a társadalom- és természettudományokkal szorosan kapcsolódó néprajzi alkotások is, melyekhez egyrészt a szaktudomány irányultsága, másrészt a nevelési célok felől közelíthetünk. Jó példa erre a népköltészet, ahol a néprajz aspektusából, az irodalomban meghatározó müfaji ismeretek elsőbbrendüségét megelőzi a minél gazdagabb szöveg- és dallammemorizálás, amely az adekvát kontextusban felidézhetö, és élményt ad előadójának és hallgatójának egyaránt. De ez az úgynevezett céltételezés nem teljesen azonosul a hagyományos tantárgyi célrendszerrel!

A néphagyomány-ismeret elválaszthatatlan részei a kézműves és mozgásos tevékenységek. A néphagyomány struktúrájában is kettős, az egyik legfőbb jellemzője a tematikus-diszciplináris felépítése, a másik a vizualitást, kézmüves tevékenységeket, az ének-zenei akusztikát és mozgást (ahol mindig a legegyszerübb szöveg, dallam, mozgástól halad az összetettebb felé) fejlesztő tárgyakhoz közelítése.

A tananyag strukturálható úgy, hogy a praktikus müveletek-, a gyakorlati tevékenység élménye felől közelítünk az tantárgy elméleti háttere felé. De sajátossága az is, hogy nem a készségek és képességek fejlesztését helyezi előtérbe, hanem az adott müveletekhez $\mathrm{s}$ az azokat végző emberekhez való viszonyulás kialakítását célozza meg. A készségek és képességek fejlesztésének elsőrendü terepe az ének, rajz, testnevelés és a technika, a néphagyomány-ismeret csak kiegészítheti az ízlést, finomíthatja a már megtanított technikákat (Baloghné, 2002).

A tanulmány további dilemmája az, hogy a pedagógus tud-e és hogyan tud bánni azokkal az immanens tartalmakkal, amelyek a speciális feladatai és azokra kellőképpen felkészült-e? Baksa Brigitta szerint a néphagyományt tanító pedagógusok inkább a tudományos ismeretekkel rendelkező elméleti szakemberek, és csak kis részük a hagyományos kultúra valamely technikáját müvelő, pedig a pedagógusok szakképzettségének kérdése nagyon nagymértékben befolyásolja a téma tanításának minőségét ${ }^{7}$. Fehér Zoltán (2010) vélekedését osztva, a folklórt (és persze a néphagyományt is) csak olyan pedagógus tudja eredményesen tanítani, aki a néprajzi jelenségeket nemcsak könyvből, filmekről, magnószalagról ismeri, hanem közvetlen „személyes” találkozása is volt a népi kultúrával (Fehér, 2010). Kováts Dániel véleménye is elfogadható, aki szerint a

\footnotetext{
${ }^{6}$ Részletesebben lásd a szerző doktori értekezésében (Gécziné, 2013).

${ }^{7}$ Kérdőíves felmérésében (2007-2009), 121 alap- és középfokú oktatási intézmény (ebből 14 budapesti) személyi feltételeinek nehézségeit tapasztalta. A megkérdezettek 5\%-a szerzett néprajzszakos képesítést, 21\%-a képezte tovább magát. Leginkább a történelem (39\%-ban a történelem szakos kolléga tanítja), rajz és a magyar tantárgyakba integrált módon (Baksa, 2010b).
} 
pedagógus akkor foglalkozik szívesen és eredményesen a néphagyománnyal, ha az ilyen irányú nevelést fontosnak tartja, az oktatásához szükséges ismeretek és módszerek birtokosa, be tudja illeszteni a tanítási folyamatba a megfelelő témaköröket és hozzá tud jutni a szükséges taneszközökhöz (Kováts, 2010b).

Azt is tapasztaltam, hogy ha a pedagógus, a néphagyomány valamelyik hagyományőrző- müvészeti vagy praktikus tevékenységet müveli (például kézművesség, hangszeres, vagy néptánc előadó, népdalénekes), az élményt adó produkció felöl tud közelíteni a tevékenysége hiteles bemutatásával.

Bábosik István gondolatai egyben a fenti kérdéskör összegzésének is tekinthetőek: „a pedagógus a maga döntően fontos modellközvetítő, kapcsolatépítő, interakciókat szabályozó szerepét a segítő-támogató-instruktívegyüttműködő magatartás mellett tudja érvényesíteni” (Bábosik, 2004. 199. o.).

\section{A tananyag meghatározásának elméleti kérdései}

A néphagyomány-ismeret tananyag meghatározásának problémakörével Zsolnai József foglalkozott behatóan. Olyan filozofikus alapokon nyugvó rendszert dolgozott ki, amelyet az emberi tevékenység objektív eredményeinek tekintett. A mindennapi életet leíró elméletek azok a tényezők, amelyek az iskola számára meghatározzák az alapvetően közvetítendő tartalmakat.

A felsorolás hosszú, ide tartozik: a játékkultúra, a humor, a test- és egészségkultúra, a gazdaság és ökonómia, a technikai és technológiai kultúra, a környezet és környezetvédelem, a társadalom, a politika és politikatudomány, a jog és jogtudomány, az erkölcs és etika, a vallás, ateizmus és vallásszociológia, a müvészet és esztétika, a tudomány és tudománytan, az információs és kommunikációs kultúra, a munka, munkamegosztás és munkatudomány, a népek és kultúrák, a történelmi kultúra és történettudomány, a magyarság és magyarságkutatások, valamint a filozófia, világkép és világnézet. A 18 tagú objektivációs skálája - amely egyben az adott társadalom értékítéletét is jellemzi - átörökítéséhez tartja szükségesnek az intézményes oktatás-nevelést. Ebben a folyamatban is egyedülálló szerepe van a néphagyomány-ismeretnek, amely a kompetenciáival az objektivációs rendszer mindegyik pontjához egyaránt illeszkedik (Zsolnai, 1995).

Alapvetően a téma sajátossága az autentikus néphagyomány-ismeret, vagy a néphagyományt felelevenítő képességfejlesztés vagy a hagyományok által inspirált úgynevezett „folklorizmusjelenségek” feltárásának pedagógiai kérdései.

Összességében a néprajz mint tudomány, annak neveléstudományi kontextusban való alkalmazásával kapcsolatban felmerülő problematikára, azaz, hogy mit tekintünk néprajzi tudásnak, mi a feladata és szerepe a néprajzi ismeretek tanításának az alábbi összegezést tartom mérvadónak: „A néprajz felfogható történettudományként, szoros kapcsolatban van az esztétikával, irodalomtudománnyal, müvészettörténettel. De ugyanúgy a szociológiával és különböző gazdaságtudományokkal is. Mégis a néprajz alapvetően és mindenekelött - a kultúra tudománya, speciális szemlélete különbözteti meg a többi tudománytól. A néprajz a középpontjában az ember mindennapi élete áll, a mindennapok által felvetett kihívások és az azokra adható válaszok. Ezek pedig olyan ismeretek, amelyekre valóban minden embernek szüksége van (lehet) nap mint nap, mindennapi élete alakításában. A néprajz tehát nem csupán ideologikus tudomány, a hazaszeretet fejlesztésének, az identitás érzésének kiváló tudományos-oktatási területe, de az élethez szükséges praktikus ismeretek tárháza is, ezért beépíthetők az iskola tananyagába. 
Az irodalmi-nyelvi terület keretében a szöveges folklóralkotások népdalok, mesék, mondák, proverbiumok és találós kérdések kaphatnak helyet. Az énekzene tantárgy oktatásában, a népzene, a népdal, az énekes népi játékok. A vizuális nevelés tantárgyba a díszítőmüvészet, folklóresztétika. A testnevelés tantárgyba a mozgásos népi játékok, néptánc, a földrajzba a jelentős néprajzi tájak, etnikai csoportok, míg a történelem keretébe a tradicionális kultúra, a falusi emberek megbecsülésére, a hazaszeretetre való nevelés, másrészt praktikus müvelődéstörténeti ismereteknek a nyújtása, például az irodalmi alkotásokban lépten-nyomon felbukkanó néprajzi jelenségek megértéséhez" (Gécziné, 2013).

Tanulmányomban a néphagyomány-ismeretre vonatkoztatható sajátságos vonások felvázolására törekedtem. A néprajz relevánsan a kultúra tudománya, ideologikus volta, egyben gyakorlati orientáltsága révén az élethez szükséges praktikus ismeretek tárháza. Éppen ez a speciális szemlélete és tartalmi összetettsége különbözteti meg a többi tudománytól és a többi műveltségi területtől. A szellemi és anyagi produktumok, a szokások és normák ismerete, illetve ezek tértől és időtől függő sajátos rendszere egyben maga a klasszis tartalom is. A néphagyomány - szoros kapcsolatban a természeti és társadalmi környezettel - minden más fogalomkör elsajátítását segítő funkcióval rendelkezik. A pedagógus személye és szakmai kompetenciája meghatározó és a tervezésben is mérvadó arra vonatkozóan, hogy a néphagyomány névleges megismertetését, vagy a tanulók alkotó bevonását választja. Maga a téma demonstrálja azt, hogy minden részismeret egymással szoros kontextusban összefonódva befolyással bír az életmódra a világlátásra vonatkozóan, ami indoka a néphagyomány-ismeretek tanításának.

\section{Irodalom}

Andrásfalvy Bertalan (1998): A néphagyomány oktatásának távlatai. In: Karácsony M. Erika és Kraiciné Szokoly Mária (szerk.): Hon- és népismeret, néphagyomány az oktató-, nevelömunkában, BTF, Budapest. 8-10.

Andrásfalvy Bertalan (2010): Néphagyomány és müvelődés. In: Honismeret/Hagyományátadás. Honismereti Szövetség, Budapest.

Ágh Zsófia (1998): Kultúra-multikultúra, a néprajztanítás elméleti és gyakorlati problémái. In: Karácsony M. Erika és Kraiciné Szokoly Mária (szerk.): Hon-és népismeret, néphagyomány az oktató-, nevelömunkában, BTF, Budapest. 38.

Baloghné Zsoldos Julianna (2002): A néphagyomány az iskolában. Pedellus Kiadó, Debrecen.

Bausinger, H. (1995): Népi kultúra a technika korszakában. Osiris-Századvég, Budapest.

Bábosik István (2004): Neveléselmélet. Osiris Kiadó, Budapest.

Benedek Krisztina és Sándor Ildikó (2006, szerk.): Útravaló - A néphagyomány közvetitésének módszerei az óvodában. Hagyományoktatás Módszertani füzetek, Hagyományok Háza - Népmúvészeti Mühely, Budapest.

Benedek Krisztina és Sándor Ildikó (2010a, szerk.): Útravaló - A néphagyomány közvetitésének módszerei az iskolában. Hagyományoktatás Módszertani füzetek, Hagyományok Háza-Népmúvészeti Módszertani Mühely, Budapest.

Gécziné Laskai Judit (2009): Útravaló I. (könyvajánló). Új Pedagógiai Szemle, 2009/8-9. 243-247. 
Farkas Mária (1997): Az Ember és társadalom müveltségi terület és a múltismeret a történelmi olvasmányok tükrében. In: Hangay Zoltán (szerk.): Ember és társadalom müveltségi terület feldolgozása. BTF, Budapest. 16-29.

Fehér Zoltán (2010): A folklór a kerettantervben és az iskolai gyakorlatban, In: Hagyományátadás - Módszertani segédanyag. Honismeret-Különszám, Honismereti Szövetség, Budapest.

Gráfik Imre (2007): Kézjegy. Kézmủves hagyomány, mint védjegy, avagy az eredetiség garanciája, In: Wilhelm Gábor (szerk.): Hagyomány és eredetiség, Tabula könyvek 8. Néprajzi Múzeum, Budapest.

Gécziné Laskai Judit (2011): A (nép)hagyományismeret körébe utalható néprajzi, kulturális antropológiai, pedagógiai és neveléselméleti definíciók. Kútbanézók, XVIII. $13-35$.

Gécziné Laskai Judit (2013): Hagyományismereti tankönyvek. Doktori disszertáció. ELTE-PPK. Budapest.

Józsa Péter (1986): Vizsgálatok a kulturális értékek befogadásáról, az esztétikai élmény nyomában. Müvészetszociológiai és szemiotikai tanulmányok, Akadémiai Kiadó, Budapest.

Klaniczay Gábor (1993): Gondolatok a népi kultúra, a szubkultúra és az ellenkultúra viszonyáról. In: Fekete Éva (szerk.): Múltunk jövője. Szabadelvüek a népi kultúráról. T-Twins Kiadó, Budapest.

Kováts Dániel (2010): A tanító és tanárképző főiskola szerepe a helyismeret tanítására való felkészítésben. In: Halász Péter (szerk.) Hagyományátadás-Módszertani segédanyag, Honismeret-Különszám, Honismereti Szövetség, Budapest.

Kraiciné Szokoli Mária (1998): Posztmodern kor - hagyomány - oktatás. In: Karácsony M. Erika és Kraiciné Szokoly Mária (szerk.): Hon- és népismeret, néphagyomány az oktató-, nevelömunkában. BTF, Budapest. 15-22.

Kuncze Gábor (1993): Üdvözlő szavak. In: Fekete Éva (szerk.): Múltunk jövője Szabadelvüek a népi kultúráról. T-Twins Kiadó, Budapest.

Lágler Péter (1981): A népmüvészet nemzetközisége és prezentációi. letöltés helye: http://www.mmi.hu/vallalkozoi_konferencia/vallakozoi_konf08_lagler/vallakozoi_ko nf08_lagler.pdf letöltés ideje: 2013.február 11.

Németh András (2005): Az életreform és annak magyar pedagógiai recepciója: életreform és művelődési reform. In: Németh András, Mikonya György és Skiera Ehrenhard (szerk.): Életreform és reformpedagógia - Nemzetközi törekvések - A magyar pedagógia recepciója. Gondolat Kiadó, Budapest.

Németh László (1973): A kísérletező ember. Magvető és Szépirodalmi Könyvkiadó, Budapest.

Radnóti Katalin (1995): Komplex természettudomány a magyar fizikatankönyvek tükrében régen és ma. Iskolakultúra, 5. 8-9. sz. 79-94.

Tarján Gábor (1995): Fölnevelö hagyomány. Magyar Médiapedagógiai Mühely, Budapest.

Trencsényi László (1993): A tiszta forrás vize - kólás dobozból. Iskolakultúra, 3. 6. sz. 97-99.

Trencsényi László (2012): Új kihívások-régi értékek. In: Karikó Sándor (szerk.): Középpontban a pedagógus - Régi értékek-új kihivások, Áron Kiadó, Budapest. 
Kell-e és lehet-e a néphagyományt tanítani/tanulni?

Zsolnai József (1995): Az értékközvetitö és képességfejlesztő pedagógia. Tárogató Kiadó, Budapest. 